\title{
Microfacies and Sedimentary Environments of the Fahliyan Formation from the Southwest of Iran (Shiraz, Zagros)
}

\author{
Mahnaz Parvaneh Nejad Shirazi", Fatemeh Dashtaby Jahromi, Mohammad Bahrami \\ Departement of Geology, Payame-Noor University, Tehran, Iran \\ Email:"mahnaz402002@yahoo.com
}

Received December 9, 2012; revised January 8, 2013; accepted February 8, 2013

Copyright (C) 2013 Mahnaz Parvaneh Nejad Shirazi et al. This is an open access article distributed under the Creative Commons Attribution License, which permits unrestricted use, distribution, and reproduction in any medium, provided the original work is properly cited.

\begin{abstract}
The Fahliyan Formation is a carbonate sequence of Lower Cretaceous (Berriasian-Hauterivian) in age and was deposited in the Zagros sedimentary basin. This formation is a part of Khami Group and is a reservoir rock in Zagros Basin. This formation was investigated by a detailed petrographic analysis in order to clarify the depositional facies and sedimentary environment in the Kuh-e-Gadvan in Fars Province. Petrographic studies led to the recognition of nine microfacies that were deposited in four facies belts: tidal flat, lagoon, and barrier and shallow open-marine. An absence of turbidite deposits, reefal facies, and gradual facies changes indicate that the Fahliyan Formation was deposited on a carbonate ramp.
\end{abstract}

Keywords: Microfacies; Sedimentary Environments; Faliyan; Shiraz; Zagros

\section{Introduction}

The Fahliyan Formation is part of the Lower Cretaceous (Berriasian-Hauterivian) deposits of southwest of Iran. This formation is one of the important hydrocarbon reservoirs for Khami group in southwest of Iran. Lithologically, the Fahliyan Formation at the type section consists of 332 meters of mainly limestone and argillaceous limestone [1].

It was deposited on a carbonate platform developed across the Zagros Basin. Little work has been done on the effects of relative sea level changes during deposition of the Cretaceous carbonate sediments in the Zagros Basin. In this research, Fahliyan Formation was investigated in a surface section of Kuh-e-Gadvan in the Folded Zagros Zone. Since there aren't any studies on the microfacies of Fahliyan Formation at Kuh-e-Gadvan or the related reports are not available and also study on other properties are not enough, the main objectives of this paper are to 1) describe and interpret the microfacies of deposits of Fahliyan Formation and 2) describe and interpret the depositional environments represented by the Fahliyan Formation.

\footnotetext{
*Corresponding author.
}

\section{Studied Area}

The studied area is located at the northeast of Kuh-eGadvan, $45 \mathrm{~km}$ northeast of Shiraz in the Folded Zagros Zone. Geographically, the area is part of the Fars Province. Field work was concentrated at the southern flank of Gadvan anticline in the southwestern vicinity of Khuraki village, about $15 \mathrm{~km} \mathrm{SE}$ of Dariyan city. A stratigraphic section was measured in detail along the northern and southern slopes of a mountain crossing the northern flank of an anticline at N: $29^{\circ} 37^{\prime} 15^{\prime \prime} / \mathrm{E}$ : 52 $58^{\prime} 40^{\prime \prime}$ (Figure 1).

\section{Materials and Methods}

Fahliyan Formation at Kuh-e-Gadvan, with a thickness of 325 meters, is consisting of thin to thick bedded limestones (Figure 2). The first stage includes data on relevant studiesdone on this formation. The Samples were taken almost every three meters and sampling was based on facies variations. More than 125 thin sections were prepared and stained with Alizarin Red S. Then laboratory works start and paying study of thin section. Carbonate rocks were classified following Dunham [2]. Depositional processes were interpreted from the presence of ske- 
letal and non-skeletal components, sedimentary strucstratigraphic section. The Fahliyan Formation overlies the
Surmeh Formation disconformably and is underlain by the Gadvan Formation conformably (Figures 1-3).

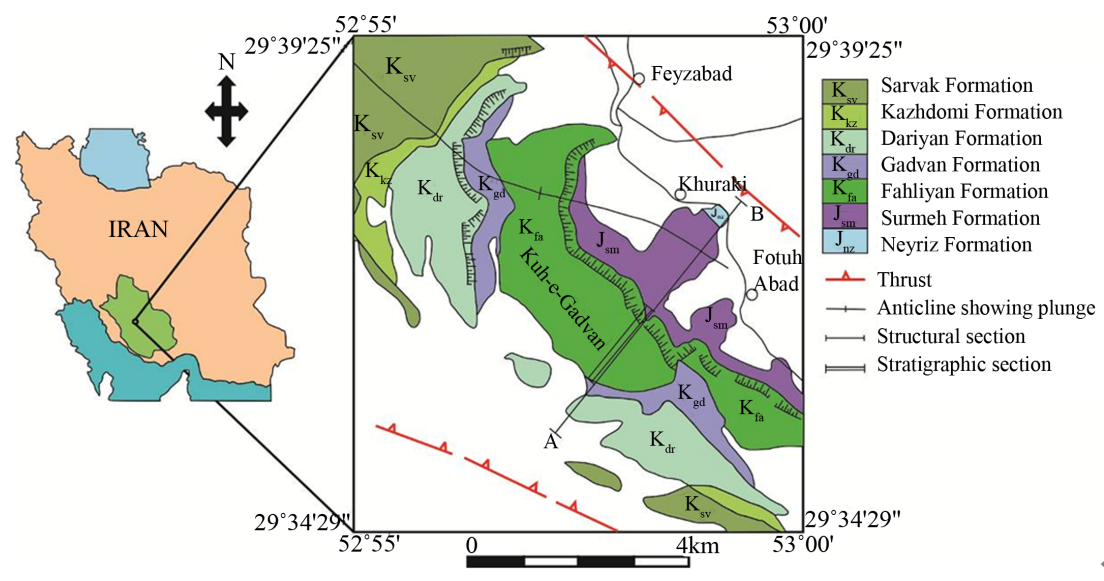

Figure 1. Geological map of studied area.

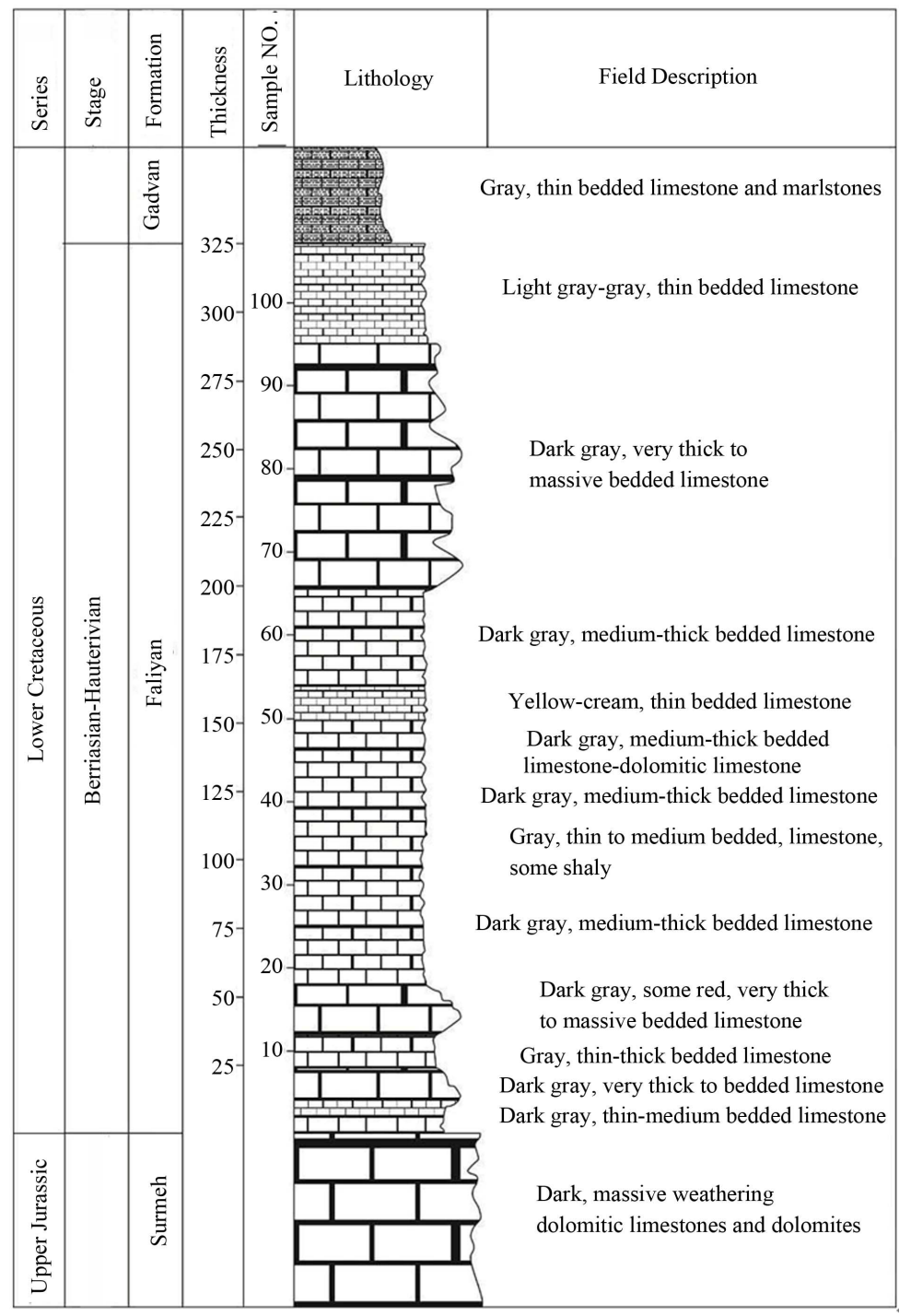

Figure 2. Lithostratigraphic column of Fahliyan Formation in the studied area. 


\section{Results and Discussion}

\subsection{Microfacies}

Fahliyan Formation in the studied section consists of the following four facies belts, facing sea from the coast: tidal flat (T), lagoon (L), barrier (B) and open marine (O).

\subsubsection{Tidal flat microfacues $(\mathrm{T})$}

\section{Dolomitic Mudstone}

Features such as fenestral fabric, evaporate molds, microbial filaments, mud cracks, and anhydrite nodules in a dolomicrite matrix are observed abundantly in this microfacies (Figure 4). This facies has intensively been influenced by diagenetic processes. Comparing with modern carbonate environments such as Persian Gulf [8], this microfacies has been deposited at upper parts of tidal flats in a warm and arid region.

\subsubsection{Lagoon Microfacies}

\section{1) Peloidal Packstone/Grainstone (L1)}

The frequency of appearance of peloidal packstone/ grainstone is relatively higher in this section and is found at a number of levels. It is commonly composed of peloidal grains, having micritic composition. These microfacies are also found in associations with foraminifera (Figure 5).

This microfacies is interpreted as indicating the presence of a restricted marine shelf lagoon environment similar to Wilson [3] facies belt 8, SMF 16 and Flügel [4].

2) Algal Foraminiferal Packstone/Wackestone (L2)
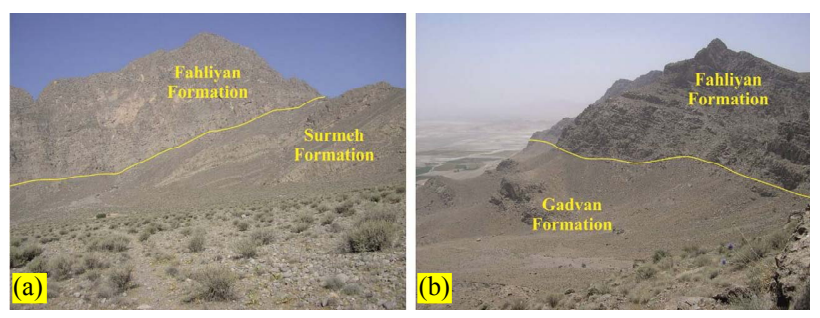

Figure 3. (A) A northwest view of Kuh-e-Gadvan (lower boundary of Fahliyan Formation with Surmeh Formation) and (B) A southeast view of Kuh-e-Gadvan (upper boundary of Fahliyan Formation with Gadvan Formation).
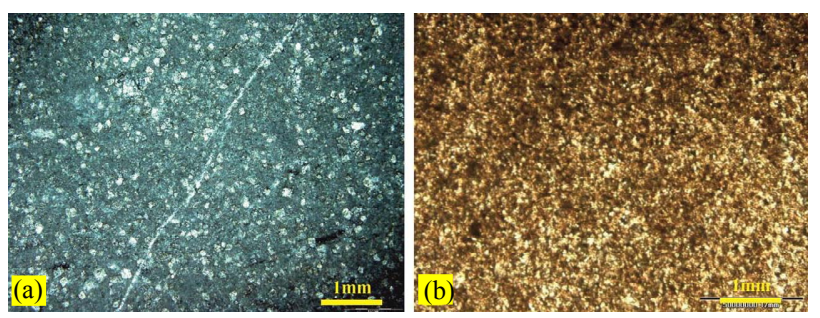

Figure 4. Photomicrographs showing a dolomitic mudstone (T).
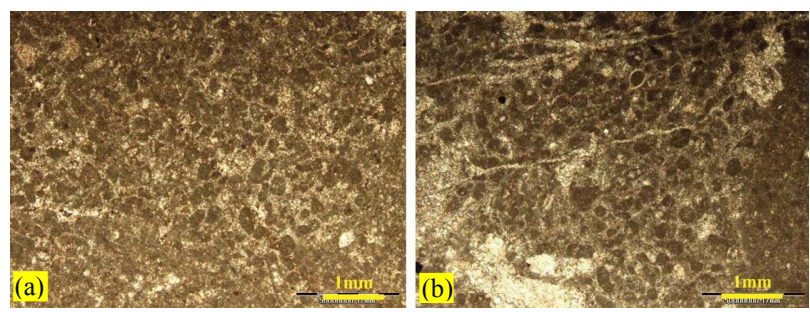

Figure 5. Photomicrographs showing a peloidal packstone/ grainstone (L1).

This micorfacies can be comparable with SMF 18 [9] and has micrite and microsparite matrix, in addition to very rare planktonic foraminifera, rare small benthic foraminifera, and dacycladacean algae (Figure 6). The bioclasts and coralline algal debris are selective dissolute, opened in some parts and partially cemented in others by fine to medium granular and equigranular mosaic cement. This microfacies represents collaboration in action of near or at stormwave base of turbidity character in shallow open marine in lagoon environment with moderate circulation.

3) Foraminferal Packstone/Wackestone (L3)

This facies can be comparable with SMF 10 [9]. The major combination of this facies is high percent of foraminifers and their main structure is wackestone. Their major allochem constituents are orbitolina, pseudocyclamina, echinoderm, and bivalve (Figure 7). The space between allochems are filled by micrite and mud supported fabric has been given. The life environment of foraminifer benthic generally is small limited and stripped from the depth and also in waters with normal salt (35\%). Orbitolins which is from foraminifers is seen in reefs. They have important comparable biostratigraphy.

\subsubsection{Barrier Microfacies}

1) Bioclastic Packstone/Wackestone (B1)

This facies is composed mainly of gray to dark grey, with yellow to cream, thin-medium bedded limestone.

The macrofossils present as whole shells; echinoids, cephalopods and foraminifers are the most important fossil groups in this facies. Microscopically, this section shows abundant bioclasts of echinoids, dasycladacean algae, and few benthonic foraminifers, embedded in a matrix of micrite. The cement is mostly blocky sparry calcite and constitutes less than 10\%. Figure 8 shows the results of Microscopic investigations of this microfacies bioclastic packstone/wackestone. This microfacies is similar to SMF 10 of Wilson [3], indicating a lagoon environment. This is supported by the very limited whole fossils, mainly cephalopods and echinoids, which indicate a quiet environment, and the presence of dasycladcean algae and benthonic foraminifera is abundant.

2) Cortoidal Packstone/Grainstone (B2)

The cortoids are one of types of coated grains and are 


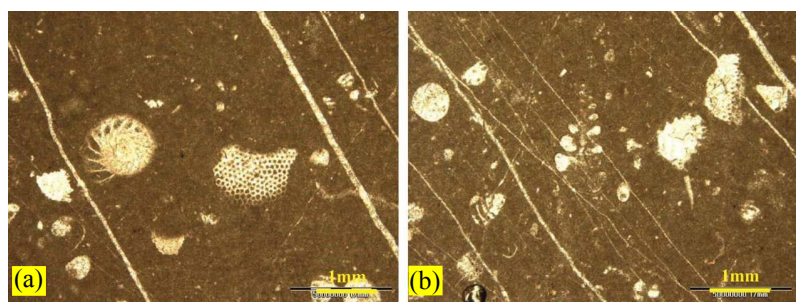

Figure 6. Photomicrographs showing an algal foraminiferal packstone/wackstone (L2).

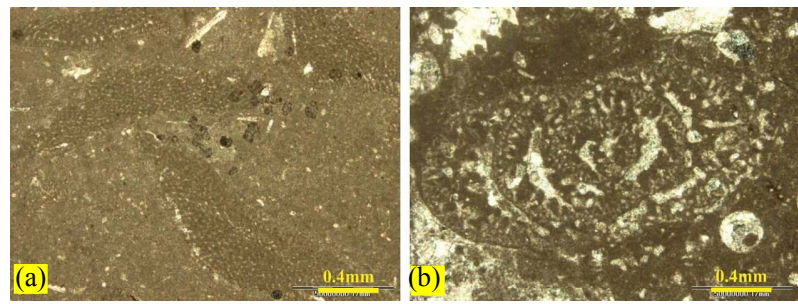

Figure 7. Photomicrographs showing a foraminiferal packstone/wackestone (L3).

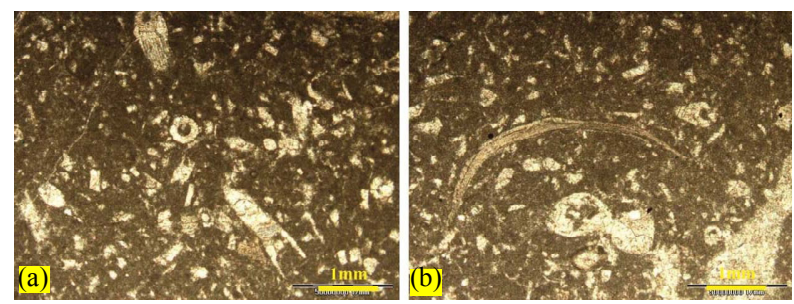

Figure 8. Photomicrographs showing a bioclastic packstone/ wackestone (B1).

covered by micritic envelope only. These grains actually constitute a type of non-laminated coated grains [10]. This microfacies of grainstone has been recorded in (Figure 9). The frequency of their appearance in other microfacies is relatively low. This microfacies is interpreted as indicating the presence of a barrier environment similar to Wilson [3] facies belts 5 or 6 , SMF 11 and Flügel [4].

3) Rudist Boundstone (B3)

The major allochem of this facies is rudist which includes the whole section and the space between them has been filled by micrite (Figure 10). Rudist is among of reef creatures. Growing beside each other make peace the space between them and as the result, mud forming between them and two separate decks will be connected by mud and make a massive, and give name of boundstone to the stone.

This microfacies is interpreted as indicating the presence of a barrier environment similar to Wilson [3] facies belt 5, SMF 7 and Flügel [4].

4) Lithocodium Aggregatum Boundstone (B4)

The major allochem of this facies is lithocodium aggregatum (Figure 11). Lithocodium aggregatum is among of reef creatures. This facies can be comparable with
SMF 7. Growing beside each other make peace the space between them and as the result, mud forming between them and two separate decks will be connected by mud and make a massive.

This microfacies is interpreted as indicating the presence of a barrier environment similar to Wilson [3] facies belt 5 and Flügel [4].

\subsubsection{Open Marine Microfacies}

Radiolarian Mudstone (O)

The components are composed mostly of radiolarian, spicules and calcified spines of radiolarian, besides planktonic foraminifera. The radiolarian tests were almost fully replaced by calcite, and in some cases they were only partly preserved (Figure 12). Such facies are widespread, in carbonate deposits formed in bathyal environments [9].

Radiolarians are exclusively marine planktonic unicellular organisms consisting of siliceous (opaline) skeletons with sizes less than $2 \mathrm{~mm}$, usually ranging between $(100-250) \mu \mathrm{m}$. They populate in open marine environments. In the present-day oceans, and can be found at depths ranging from 100 meters to more than 4000
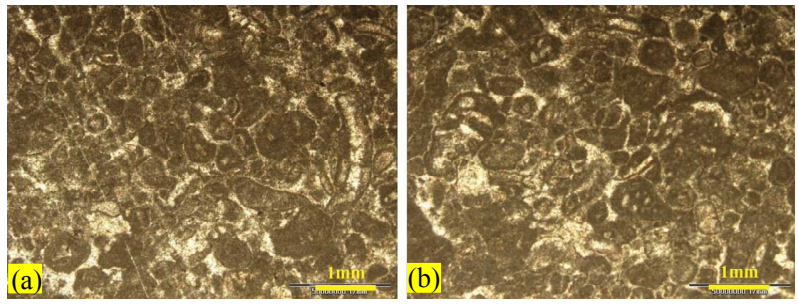

Figure 9. Photomicrographs showing a cortoidal packstone/ grainstone (B2).
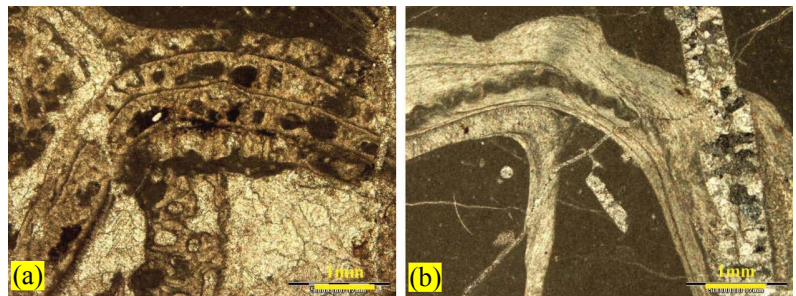

Figure 10. Photomicrographs showing a rudist boundstone (B3).
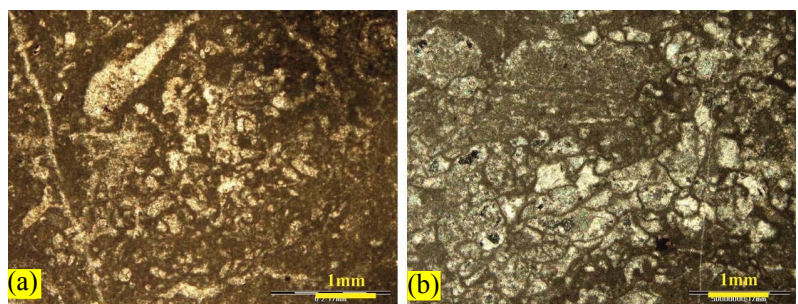

Figure 11. Photomicrographs showing a lithocodium aggregatum boundstone (B4). 
meters (Flügel, 2004). Fossil radiolarians were found in basinal pelagic limestones [11], but also in shallower sediments.

\subsection{Depositional Environment}

After recognition and detailed study on the microfacies and their classification, regarding Walter rule and the arrangement of overlaying microfacies over each other, their comparison with present and older environment [5], [12], evidences such as lack of dais laced and reworked deposits, absence of slides and slumps facies that indicate high slope of depositional environment during sedimentation, it can be concluded that the microfacies of Fahliyan Formation is involved in shallow depth marine environment. Regarding the studies conducted on the profiles on Fahliyan Formation [13] some evidences have been found on the reworked facies therefore, it is believed that the depositional model of Fahliyan Formation is a carbonate shelf and the profile studied was situated at the shallowest part of the platform (Figure 13).

The proposed model includes tidal flat, lagoon, barrier and open marine which are distinguished from each other based on the sedimentary characteristics, difference in energy level, salinity, rate of sedimentation and diversity in the biological assemblage, reconstructed based on facies group continuity.

\section{Conclusion}

The Fahliyan Formation in the studied section is composed of carbonates. The petrographic studies reveal nine types of microfacies which are: dolomitic mudstones, peloidal packstones/grainstones, algal foraminiferal packstones/wackestones, foraminiferal packstones/wackestones,
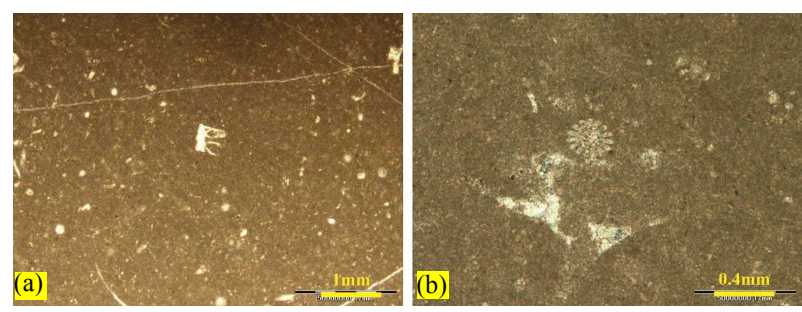

Figure 12. Photomicrographs showing a radiolarian mudstone $(0)$.

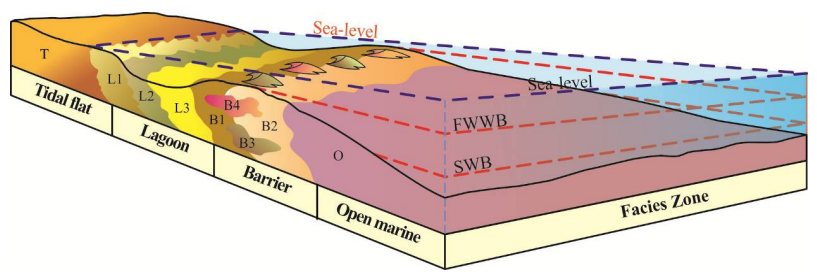

Figure 13. Depositional model of Fahliyan Formation at Kuh-e-Gadvan. bioclastic packstones/wackestones, cortoidal packstones/ grainstones, rudist boundstones, lithocodium aggregatum boundstones, and radiolarian mudstones. The analytical studies of these microfacies lead towards the inference that the Fahliyan Formation deposited in the carbonate shelf and the profile studied was situated at the shallowest part of the platform. The allochemical component grains are predominantly bioclastic, tests and particles, which mostly belongs to benthonic foraminifers. Other skeletal grains show a diversity of species, which include echinoderms, sponges, rudists, and algae.

\section{Acknowledgements}

The Authors appreciate Payame-Noor University for providing the laboratory facility.

\section{REFERENCES}

[1] G. A. James and J. G. Wynd, "Stratigraphic Nomenclature of Iranian Oil Consortium Agreement Area," AAPG Bulletin, Vol. 49, No. 12, 1965, pp. 2182-2245.

[2] R. J. Dunham, "Classification of Carbonate Rocks According to Depositional Texture," AAPG Memoir, Vol. 1, 1962, pp. 108-121.

[3] J. L. Wilson, "Carbonate Facies in Geological History," Springer-Verlag, Berlin, 1975. doi:10.1007/978-1-4612-6383-8

[4] E. Flügel, "Microfacies Analysis of Limestones," Springer-Verlag, Berlin, 1982. doi:10.1007/978-3-642-68423-4

[5] A. V. Carozzi, "Carbonate Rocks Depositional Model," Prentice Hall, Upper Saddle River, 1989.

[6] G. Einsele, "Sedimentary Basins; Evolution, Facies and Sediment Budget," Springer-Verlag, Berlin, 2000.

[7] M. E. Tucker, "Sedimentary Petrology," 3rd Edition, Blackwell, Oxford, 2001.

[8] G. Friedman, "The Arid Peritidal Complex of Abudhabi: A Historical Perspective," Carbonates and Evaporites, Vol. 10, No. 1, 1995, pp. 2-7. doi:10.1007/BF03175237

[9] E. Flügel, "Microfacies of Carbonat Rocks Analysis, Interpretation and Application," Springer-Verlag, Berlin, 2004.

[10] M. E. Tucker and V. P. Wright, "Carbonate Sedimentology," Blackwell Scientific Publication, Oxford, London, 1990. doi:10.1002/9781444314175

[11] B. Kuhry, et al., "Indications of Current Actions in Late Jurassic Limestones, Radiolarian Limestones, Saccocoma Limestones and Associated Rocks from the Subbetic SE Spain," Sedimentary Geology, Vol. 15, No. 3, 1976, pp. 235-258. doi:10.1016/0037-0738(76)90018-X

[12] G. J. Nichols, "Sedimentology and Stratigraphy," Blackwell Science, Oxford, 1999.

[13] Y. Lasemi and K. Nourafkan, "Sequence Stratigraphic Control on Prolific HC Reservoir Development, Southwest Iran," Oil and Gas Journal, Vol. 106, 2008, pp. 1-6. 